\title{
PENERAPAN METODE STAD DISERTAI MEDIA TORSO UNTUK MENINGKATKAN AKTIVITAS DAN HASIL BELAJAR BIOLOGI
}

\author{
Riska Agusrio Saputra \\ Handoko Santoso \\ Pendidikan Biologi FKIP Universitas Muhammadiyah Metro \\ E-mail: riodiansaputra@ymail.com
}

\begin{abstract}
The results addressing the STAD method Torso with Media can improve biological activity and learning outcomes food Digestive System subject matter in class XI Science High School PGRI Bukitkemuning Academic Year 2012/2013. Student activity data on average in the first cycle by $63 \%$ in the second cycle obtained an average learning activity by $72 \%$ with an increase of $9 \%$ while for the learning outcomes of students has increased, the average initial score was 53.2 before PTK implemented, and at the end of the first cycle of 65.14, then on the second cycle of 72.28. To obtain an average yield improvement of student learning from cycle I to cycle II at $7.14 \%$, even when compared with the prior PTK increased 35.86\%. As for the suggestions to teachers fields of study, in order to study biological activities and results to achieve optimal results it is recommended to apply the methods of cooperative learning with media type STAD Torso by optimizing activities ask, discuss, do chores, and making observations.
\end{abstract}

Key Words: STAD, learning activities, learning outcomes

Pendidikan merupakan suatu aktivitas yang terencana untuk mencapai suatu tujuan pendidikan yang telah ditetapkan, namun banyak faktor yang menentukan keberhasilan pendidikan. Secara garis besar faktor tersebut dibedakan menjadi dua yaitu faktor intern dan faktor ekstern. Faktor intern yaitu berupa motivasi, kesehatan, bakat, intelegensi dan kemampuan yang dimiliki anak didik, sedangkan faktor ekstern yaitu berupa fasilitas belajar sarana dan prasarana sekolah, guru, orang tua, media pendidikan, atau alat peraga dan metode mengajar yang dipergunakan oleh seorang guru.

Dalam proses pembelajaran guru mempunyai peranan untuk menentukan suatu metode pembelajaran yang efektif dan mendukung siswa mendapatkan pengalaman belajar yang berharga. Pengalaman belajar sangat membantu pencapaian tujuan pembelajaran, karena siswa lebih mudah menerima pelajaran baru jika telah menguasai dasar materi tersebut.

Hasil prasurvei yang peneliti lakukan pada tanggal 10 April 2012 di SMA PGRI Bukitkemuning didapatkan nilai hasil belajar biologi kelas XI A adalah sebagai berikut. Dalam proses belajar ditemui sebagian besar siswa kurang berperan aktif, baik dalam mengajukan pertanyaan, memberikan jawaban oleh pertanyaan dari teman sekelasnya maupun dari guru. Pada kondisi seperti ini menyebabkan hasil 
belajar biologi belum mencapai maksimal.

Berdasarkan data prasurvai, menunjukkan bahwa hasil belajar masih rendah dapat dilihat bahwa siswa yang masuk katagori tidak tuntas yaitu memperoleh nilai $<70$ ada 21 siswa dengan presentase sebesar 58\%. Sedangkan harapan dari pihak sekolah adalah siswa dapat mencapai ketuntasan belajar semuanya, atau setidaknya 85\% dari jumlah siswa di setiap kelasnya. Masalah yang menyebabkan siswa tidak tuntas dalam belajar yaitu sebagian besar siswa tidak berperan aktif dalam proses belajar, siswa lebih banyak diam saat guru mengajukan pertanyaan, sulitnya memahami pelajaran dan kurangnya siswa mengajukan pendapat sehingga proses pembelajarannya berpusat pada guru dan laboratorium tidak berfungsi.

Kunandar (2008:277) menyatakan bahwa "hasil belajar dapat dilihat dari hasil nilai ulangan harian (formatif), ulangan harian tengah semester (sumatif) dan nilai ulangan semester (sumatif). Penilaian yang dilakukan terhadap siswa bertujuan untuk mengetahui apakah siswa telah menguasai suatu materi atau belum”.

\section{METODE}

Penelitian ini menggunakan pendekatan Penelitian Tindakan Kelas (PTK), dilaksanakan pada semester genap di SMA PGRI Bukitkemuning Tahun Pelajaran 2012/2013, yang menjadi subjek penelitian adalah siswa kelas XI IPA yang berjumlah 35 siswa dengan tingkat kemampuan yang beragam. Sedangkan objek penelitian metode Student Team Achievement Division (STAD) disertai Media Torso dalam meningkatkan aktivitas dan hasil belajar siswa pada materi pokok Sistem Pencernaan Makanan. Pelaksanaan penelitian ini dimulai pada tanggal 05 Januari 2013 dan berakhir pada tanggal
25 Januari 2013. Penelitian dilaksanakan 2 siklus, masing-masing siklus terdiri dari 3 kali pertemuan yang setiap pertemuannya terdiri dari 2 jam pelajaran (2x45 menit).

Dalam penelitian, peneliti melakukan tahap-tahap penelitian dengan kegiatan pada tahap perencanaan yaitu bersama guru mengkaji materi yang akan dilakukan dalam proses pembelajaran selama penelitian, setelah itu mempersiapkan segala perangkat pembelajaran yang akan digunakan selama penelitian seperti silabus, rencana pelaksanaan pembelajaran, membuat lembar observasi siswa yang digunakan untuk melihat aktivitas siswa selama proses pembelajaran berlangsung, membuat LKS, dan soal evaluasi pembelajaran. Pelaksanaan tindakan dilakukan oleh peneliti dengan melaksanakan pembelajaran dengan penerapan metode Student Team Achievement Division (STAD) disertai Media Torso .

Pada tahap observasi terhadap aktivitas siswa yang dilakukan oleh siswa. Dalam mengobservasi setiap satu kelompok dipegang oleh satu observer. Jadi dalam penelitian ini membutuhkan 5 observer supaya datanya benar-benar akurat. Pada setiap akhir siklus diadakan tes evaluasi yang digunakan sebagai tolak ukur akan kemampuan untuk memahami materi oleh siswa yang diberikan oleh peneliti dan guru. Pada tahap terakhir adalah refleksi dilakukan pada setiap akhir siklus dalam mengkaji pembelajaran yang dilakukan.

\section{HASIL}

Berdasarkan hasil observasi pada penelitian yang telah dilakukan, aktivitas siswa mengalami peningkatan dari siklus I ke siklus II. Hal tersebut dapat dilihat pada Tabel 1. Dari Tabel 1, dapat dilihat bahwa aktivitas siswa yang menjadi indikator dalam penelitian dengan 
menggunakan metode Student Team Achievement Division (STAD) disertai Media Torso telah mengalami peningkatan, dan semua aspek aktivitas telah mencapai target yang diinginkan sebagai indikator keberhasilan.

Berdasarkan hasil tes yang dilakukan, hasil belajar siswa pada pra PTK, siklus I dan siklus II mengalami peningkatan. Peningkatan hasil belajar ini juga ditunjukan oleh peningkatan jumlah siswa yang telah tuntas belajar. Peningkatan hasil belajar siswa tersebut dapat dilihat pada Tabel 3.
Berdasarkan Tabel 3 nilai rata-rata belajar siswa meningkat dari setiap siklusnya. Pada siklus I rata-rata hasil belajar siswa 65,14 sedangkan pada siklus II menjadi 72,28 sehingga terjadi peningkatan sebesar 7,14 pada siklus I siswa yang mendapat nilai sesuai dengan $K K M \geq 70$ sebanyak $57 \%$ sedangkan pada siklus II hasil belajar siswa meningkat menjadi 83\%, hal tersebut karena siswa sudah mulai terbiasa menggunakan Metode STAD disertai Media Torso.

Tabel 1. Perbandiangan Aktivitas Siswa Siklus I dan Siklus II

\begin{tabular}{|l|l|c|c|c|}
\hline No & Aspek yang diamati & Siklus I & Siklus II & Peningkatan \\
\cline { 3 - 4 } & & Rata-rata & Rata-rata & \\
\hline 1 & $\begin{array}{l}\text { Memperhatikan guru } \\
\text { menerangkan }\end{array}$ & $81 \%$ & $85 \%$ & $4 \%$ \\
\hline 2 & Mencatat materi & $83 \%$ & $87 \%$ & $4 \%$ \\
\hline 3 & Mengajukan pertanyaan & $22 \%$ & $31 \%$ & $9 \%$ \\
\hline 4 & Mengerjakan tugas & $82 \%$ & $89 \%$ & $7 \%$ \\
\hline 5 & Berdiskusi dan bekerja sama & $57,13 \%$ & $80,38 \%$ & $23 \%$ \\
\hline 6 & Melakukan pengamatan & $52,37 \%$ & $59,14 \%$ & $7 \%$ \\
\hline \multicolumn{2}{|r|}{ Rata-rata } & $63 \%$ & $72 \%$ & $9 \%$ \\
\hline
\end{tabular}

Tabel 3. Data Peningkatan Hasil Belajar Siswa

\begin{tabular}{l|l|l|c|c|c|c|c}
\hline \multirow{2}{*}{ No } & Kategori & Nilai & \multicolumn{2}{|c|}{ Banyak siswa } & \multicolumn{2}{c|}{ Persentase } & \multirow{2}{*}{$\begin{array}{c}\text { Peningka } \\
\text { tan }\end{array}$} \\
\cline { 3 - 6 } & & $\begin{array}{c}\text { Siklus } \\
\text { I }\end{array}$ & $\begin{array}{c}\text { Siklus } \\
\text { II }\end{array}$ & $\begin{array}{c}\text { Siklus } \\
\text { I }\end{array}$ & $\begin{array}{c}\text { Siklus } \\
\text { II }\end{array}$ & \\
\hline 1 & Tuntas & $\geq 70$ & 20 & 29 & $57 \%$ & $83 \%$ & 7,14 \\
\hline 2 & $\begin{array}{l}\text { Tidak } \\
\text { Tuntas }\end{array}$ & $\leq 70$ & 15 & 6 & $43 \%$ & $17 \%$ & \\
\hline \multicolumn{3}{c|}{ Jumlah } & 35 & 35 & $100 \%$ & $100 \%$ & \\
\hline \multicolumn{2}{l|}{ Nilai rata-rata belajar siswa } & & 65,14 & 72,28 & \\
\hline
\end{tabular}


PEMBAHASAN

Untuk hasil pembelajaran yang optimal dalam proses pembelajaran salah satu faktor yang perlu dipertimbangkan adalah penggunaan metode yang tepat yang disesuaikan dengan materi pelajaran dan tujuan pembelajaran yang hendak dicapai. Berdasarkan hasil penelitian yang telah diuraikan di atas, maka diketahui gambaran tentang bagaimana pembelajaran dengan menggunakan metode STAD disertai Media Torso. dalam meningkatkan aktivitas siswa dan hasil belajar biologi siswa pada materi sistem pencernaan makanan.

\section{Peningkatan Aktivitas Belajar}

Peningkatan aktiviats siswa selama proses pembelajaran ini merupakan penerapan metode Student Team Achievement Division (STAD) disertai Media Torso . Hasil penelitian ini mendukung penelitian sebelumnya oleh Surtini (2009) pada pelajaran biologi. Penelitian ini yang telah dilakukan peneliti tersebut menunjukan bahwa pembelajaran dengan menggunakan aktivitas metode STAD dapat meningkatkan aktivitas siswa dalam berdiskusi dan kerjasama. Seperti yang dikemukakan oleh Rousseau (dalam Sardiman, 2009:96) memberikan penjelasan bahwa segala pengetahuan itu harus diperoleh dengan pengamatan sendiri, pengalaman sendiri, penyelidikan sendiri dengan bekerja sendiri, dengan fasilitas yang diciptakan sendiri, baik secara rohani maupun teknis.

\section{Peningkatan Hasil Belajar}

Peningkatan ini dikarenakan pembelajaran yang dilakukan dengan metode Student Team Achievement Division (STAD) disertai Media Torso dapat meningkatkan hasil belajar siswa. Karena pembelajaran secara langsung dengan objek dapat meningkatkan ingatan yang lebih mendalam kepada siswa. Selain itu siswa yang menemukan sendiri jawaban dari permasalahan yang ada berdasarkan pengamatan. Hasil penelitian tersebut seperti dikemukakan menurut Kunandar (2007:251) bahwa hasil belajar adalah kemampuan siswa dalam memenuhi suatu tahapan pencapaian pengalaman belajar dalam satu kompetensi dasar. Hasil belajar berfungsi sebagai petunjuk tentang perubahan perilaku yang dicapai siswa sehubungan dengan kegiatan belajar yang dilakukan.

\section{KESIMPULAN DAN SARAN Kesimpulan}

Berdasarkan hasil penelitian tindakan kelas yang dilakukan dengan menggunakan metode Student Team Achievement Division (STAD) disertai Media Torso dan hasil analisis data hasil penelitian serta pembahasan yang telah dikemukakan, maka dapat disimpulkan bahwa:

1. Pembelajaran dengan menggunakan Metode STAD disertai Media Torso dapat meningkatkan aktivitas belajar biologi siswa kelas XI IPA semester genap SMA PGRI Bukitkemuning tahun pelajaran 2012/2013. Hal ini dapat dilihat dari peningkatan ratarata persentase aktivitas belajar siswa dari siklus I adalah 63\% ke siklus II adalah 72\%. Kemudian didapatkan rata-rata aktivitas belajar siswa dari siklus I ke siklus II adalah sebesar 9\%.

2. Pembelajaran dengan menggunakan Metode STAD disertai Media Torso dapat meningkatkan hasil belajar biologi siswa kelas XI IPA semester genap SMA PGRI Bukitkemuning tahun pelajaran 2012/2013. Hal ini dapat dilihat dari peningkatan ratarata hasil belajar siswa dari skor awal siklus I adalah 53,.2, dan pada 
akhir siklus I adalah 65,14, kemudian ke siklus II sebesar 72,28\%. Kemudian didapatkan ratarata hasil belajar siswa dari siklus I ke siklus II sebesar 7,14\%.

\section{Saran}

Berdasarkan kesimpulan penelitian ini, maka peneliti menyarankan untuk meningkatkan Salah satu usaha untuk peningkatan aktivitas dan hasil belajar siswa pada proses pembelajaran Biologi untuk pokok Sistem Pencernaan Makanan.

1. Untuk guru

Kepada guru bidang studi, agar aktivitas dan hasil belajar biologi siswa pada pokok bahasan sistem pencernaan pada manusia maupun materi lainya memperoleh hasil yang optimal, maka disarankan untuk menerapkan Metode STAD disertai Media Torso dengan memonotoring aktivitas yaitu mengajukan pertanyaan, memonotoring siswa mengerjakan tugas, mendampingi siswa saat berdiskusi serta bekerjasama, dan mendampingi siswa dalam melakukan pengamatan.

2. Untuk siswa

Hasil penelitian menujukan bahwa pembelajaran dengan menggunakan Metode STAD diseratai Media Torso dapat meningkatkan hasil belajar maka diharapkan agar siswa lebih memperhatikan pelajaran dan lebih aktif dalam mengikuti pembelajaran di kelas khususnya pada pelajaran biologi.

\section{DAFTAR RUJUKAN}

Kunandar. 2008. Langkah Mudah Penelitian Tindakan Kelas sebagai Pengembangan Profesi
Guru. Jakarta: Rajagrafindo Persada.

Sardiman. 2009. Interaksi dan motifasi belajar mengajar. Jakarta: PT. Raja Grasindo Persada.

Surtini. 2009. Upaya Meningkatkan Aktivitas Dan Hasil Belajar Matematika Melalui Model Pembelajaran Kooperative Tipe STAD Pada Siswa Kelas X A1 Semester Ganjil SMK Negeri 1 Metro T.P 2008/2009. Skriprsi.Universitas Muhamadiyah Metro. 